\title{
Phenology and yield response of different maize varieties to split nitrogen application under climatic conditions of Peshawar
}

\author{
Muhammad Mehran Anjum*, Muhammad Shafi, Haseeb Ahmad, Nawab \\ Ali, Jehanzeb, Muhammad Owais Iqbal, Saif Ullah and Shafiullah \\ Department of Agronomy, The University of Agriculture Peshawar KPK-Pakistan \\ *Corresponding author's email: mehrananjum@aup.edu.pk

\section{Citation} \\ Muhammad Mehran Anjum, Muhammad Shafi, Haseeb Ahmad, Nawab Ali, Jehanzeb, Muhammad Owais Iqbal, \\ Saif Ullah and Shafiullah. Phenology and yield response of different maize varieties to split nitrogen application \\ under climatic conditions of Peshawar. Pure and Applied Biology. Vol. 7, Issue 2, pp671-677.
}

http://dx.doi.org/10.19045/bspab.2018.70083

\begin{tabular}{llll}
\hline \hline Received: 11/03/2018 & Revised: 14/05/2018 & Accepted: 15/05/2018 & Online First: 17/05/2018 \\
\hline \hline
\end{tabular}

\section{Abstract}

Nitrogen losses are much higher particularly in the form of leaching and volatilization when applied to plants. Therefore, efficient techniques are required to lessen the losses of nitrogen. To study the response of different maize varieties to split nitrogen application under climatic conditions of Peshawar, an experiment was conducted at the Agronomy Research Farm of The University of Agriculture Peshawar during summer 2016. The study was conducted in randomized complete block design with split-plot arrangements with four replications. Four split nitrogen applications i.e. $180 \mathrm{~kg}$ $\mathrm{ha}^{-1}$ before sowing, $90 \mathrm{~kg} \mathrm{ha}^{-1}$ before sowing $+90 \mathrm{~kg} \mathrm{ha}^{-1}$ at knee height stage, $60 \mathrm{~kg} \mathrm{ha}^{-1}$ before sowing $+60 \mathrm{~kg} \mathrm{ha}^{-1}$ at knee height stage, $+60 \mathrm{~kg} \mathrm{ha}^{-1}$ before tasseling stage, $45 \mathrm{~kg} \mathrm{ha}^{-1}$ before sowing $+45 \mathrm{~kg}$ $\mathrm{ha}^{-1}$ at knee height stage $+45 \mathrm{~kg} \mathrm{ha}^{-1}$ before tasseling stage $+45 \mathrm{~kg} \mathrm{ha}^{-1}$ before silking stage were assigned to main plots. The varieties i.e. Pahari, Azam, Jalal and Iqbal were assigned to sub plots. Experimental results exhibited that application of nitrogen in three split $60 \mathrm{~kg} \mathrm{ha}^{-1}$ before sowing, +60 $\mathrm{kg} \mathrm{ha}^{-1}$ at knee height stage, $+60 \mathrm{~kg} \mathrm{ha}^{-1}$ before tasseling stage has delayed days to tasseling, silking and physiological maturity of maize crop and showed maximum grains row $^{-1}$ and grain yield. Among various varieties, Azam has produced maximum grains row $^{-1}$ and grain yield. It is concluded that nitrogen applied in three splits $\left(60 \mathrm{~kg} \mathrm{ha}^{-1}\right.$ before sowing $+60 \mathrm{~kg} \mathrm{ha}^{-1}$ at knee height stage $+60 \mathrm{~kg} \mathrm{ha}^{-}$ ${ }^{1}$ before tasseling stage) has prolonged the vegetative growth which resulted in higher yield and and Azam variety of maize crop also produced maximum grain yield. Nitrogen application @ $180 \mathrm{~kg} \mathrm{ha}^{-1}$ in three splits is recommended on the basis of highest grain yield. Variety Azam ranked $1^{\text {st }}$ in term of grain yield among studied varieties and recommended for general cultivation in Peshawar valley.

Keywords: Azam; Iqbal; Maize; Nitrogen, Pahari; Phenology; Split; Varieties

\section{Introduction}

Maize (Zea mays L.) is an important grain crop in the world. Maize is ranked $3^{\text {rd }}$ in term of area and production. Maize is an essential food crop with high nutrition value. Maize is also used as feed for livestock and contains $4.8 \%$ oil, $8.5 \%$ fiber, $72 \%$ starch, $10 \%$ protein, 3\% sugar and $1.7 \%$ ash [1]. In 
Pakistan maize is cultivated on an area about 1.114 and 0.447 million hectares with an average yield of $4301 \mathrm{~kg} \mathrm{ha}^{-1}$ and $1985 \mathrm{~kg} \mathrm{ha}^{-}$ ${ }^{1}$ while in Khyber Pakhtunkhwa respectively grown maize with an annual production of 4.920 and 0.887 million tons [2]. Nitrogen deficiency is the yield restricting factor which reduces grain yield $[3,4]$ reported that higher nitrogen application increases total cost of production and leaching, volatilization and immobilization. However, split application of $\mathrm{N}$ can nourish the crop better through optimum $\mathrm{N}$ uptake and thus protects the environment from the adverse effect of these chemical inputs. Likewise when deficiency of $\mathrm{N}$ occur in the crop plant so the leaf area of the plant get decreases and thus the interception of light is adversely affected [5]. Application timing of nitrogen in maize has a great importance and considered the best and appropriate for production. Nitrogen application to maize proper timing is taken at higher rates can improve nitrogen use effectiveness by diminishing the denitrification and immobilization [6, 7]. Maximum soils of the Pakistan are $\mathrm{N}$ deficient [8]. In order to get maximum and appropriate yield, increasing the nitrogen use efficiency by crop could be achieved through best management practices of nitrogen [9]. Keeping in view the importance of nitrogen application in splits on yield and performance of different maize varieties, the research was planned to find out most suitable split of nitrogen and variety/varieties for Peshawar region.

\section{Materials and methods}

The experiment was conducted at Research Farm of Agronomy, The University of Agriculture Peshawar in kharif 2016. The research was comprised of main plot factor (Split Nitrogen Application) i.e. Control, 180 $\mathrm{kg} \mathrm{ha}^{-1}$ before sowing, (90 kg ha-1 before sowing, + $90 \mathrm{~kg} \mathrm{ha}^{-1}$ at knee height stage), (60 $\mathrm{kg} \mathrm{ha}^{-1}$ before sowing $+60 \mathrm{~kg} \mathrm{ha}^{-1}$ at knee height stage $+60 \mathrm{~kg} \mathrm{ha}^{-1}$ before tasseling stage), $45 \mathrm{~kg} \mathrm{ha}^{-1}$ before sowing+ $45 \mathrm{~kg} \mathrm{ha}^{-1}$ at knee height stage $+45 \mathrm{~kg} \mathrm{ha}^{-1}$ before tasseling stage $+45 \mathrm{~kg} \mathrm{ha}^{-1}$ before silking stage and sub plot factor (varieties) i.e. (Pahari, Azam, Jalal and Iqbal). The trail was carried out in Randomized Complete Block Design (RCB) with Split Plot arrangement comprised of four replications. The sub plot was $12 \mathrm{~m}^{2}$ $(3 \mathrm{~m} \times 4 \mathrm{~m})$ in size having five rows. Nitrogen was applied from the source of Urea. Phosphorous was applied from the source of DAP. Crop was cultivated on proper moisture condition. During the crop growth \& developmental stages weeds were controlled manually as well as chemically. Haywer herbicide was sprayed at 4-5 leaf stage of weeds (25 days after sowing) of maize crop to control both broad leaf and grassy weeds. For all treatments, agronomic practices were kept uniform. When about $75 \%$ plants get emerged in each experimental unit the number of days from sowing was counted. When number of plants gets emerged so data were recorded by meter rod which was randomly placed at three different location in every experimental unit and converted to plants emerged $\mathrm{m}^{-2}$. The number of days taken till the appearance of about $75 \%$ tassels in each experimental unit was counted and recorded. The number of days taken to initiation of silking was recorded by counting from sowing to date when plants gets produced $75 \%$ silks in every subplot. Data on days taken till physiological maturity were recorded from sowing till $75 \%$ of the plants showed sign of maturity in each experimental units. Data on ear diameter was calculated by taking five ears from each sub plots after harvesting with the help of venire caliper and then averaged. After harvesting data on number of grains row $^{-1}$ were recorded by selecting ten ears randomly from each subplot and then averaged. For grain yield, four central rows were harvested, dehusked, dried, threshed and weighed through 
electronic balance for grain yield and converted to grain yield $\mathrm{kg} \mathrm{ha}^{-1}$.

\section{Statistical analysis}

The recorded data were statistically analyzed by Statistix 8.1 software used for RCBD (randomized complete block design) with split plot arrangement using F-test. Upon significant, least significant difference test (LSD) at $\mathrm{P} \leq 0.05$ was used to compare different means by the procedure described by [10].

\section{Results and discussion \\ Days to emergence}

Data concerning days to emergence of maize varieties as affected by split nitrogen application $(\mathrm{N})$ is shown in table 1. Statistical analysis of data revealed non-significant $(\mathrm{P} \geq 0.05)$ effect of split nitrogen application on days to emergence. The application of $\mathrm{N}$ in splits and combined effect of split nitrogen application and varieties and was nonsignificant. The effect of varieties on days to emergence was significant $(\mathrm{P} \leq 0.05)$. Highest value for days to emergence was observed from the treatment of Iqbal variety. Lowest days to emergence were observed from maize varieties i.e. Azam, Jalal and Pahari respectively. It may be due to the genetic potential of various varieties. Belfield \& Brown [11] reported that different varieties have different genetic potential that resulted in different performance under same situation.

\section{Emergence $\left(\mathrm{m}^{-2}\right)$}

The impact of split nitrogen application and varieties on emergence $\mathrm{m}^{-2}$ is presented in (Table 1). Split $\mathrm{N}$ application and interaction of application of $\mathrm{N}$ and varieties showed nonsignificant effect. Varieties of maize had shown significant $(\mathrm{P} \leq 0.05)$ effect on emergence $\mathrm{m}^{-2}$. Maximum emergence $\mathrm{m}^{-2}$ was recorded from Azam variety followed by Iqbal variety of maize. Minimum emergence $\mathrm{m}^{-2}$ was observed in Pahari which was statistically at par with Jalal variety. These differences indicated the existence of variability among tested cultivars. This variability might be attributed to genetic and environmental factor. Similar results were reported by [12].

\section{Days to tasseling}

Split nitrogen application and varieties of maize had significantly $(\mathrm{P} \leq 0.05)$ affected days to tasseling of maize varieties (Table 1). Interaction effect of split $\mathrm{N}$ application and varieties showed non-significant. Highest days to tasseling were observed by application of nitrogen in three split $60 \mathrm{~kg} \mathrm{ha}^{-}$ ${ }^{1}$ before sowing $+60 \mathrm{~kg} \mathrm{ha}^{-1}$ at knee height stage $+60 \mathrm{~kg} \mathrm{ha}^{-1}$ before tasseling stage followed by nitrogen applied in four splits which was statistically at par with application of nitrogen in two splits. Minimum days to tasseling were observed from control with. The possible reason might be that when the nitrogen is applied to plot at a high rate in three splits application maize crop took maximum number of days to tasseling and [13] reported similar results who stated that favorable condition for soil and nutrient availability at a highest dose has increased the rapid growth of vegetative portion of the plant and delayed the reproductive growth of the maize crop like tasseling. Maximum days to tasseling were recorded from Azam variety followed by variety of Jalal. Differences in days to tasseling among varieties of maize have indicated the existence of variability among tested cultivars. This variability might be attributed to genetic and/or environmental factor. Similar results were reported by [12].

\section{Days to silking}

Application of split nitrogen $(\mathrm{N})$ and varieties have significant impact on maize is exposed in (Table 1). Interaction among $\mathrm{N}$ and varieties showed non-significant effect. Highest values for days to silking were observed from the treatment of nitrogen applied in three split $\left(60 \mathrm{~kg} \mathrm{ha}^{-1}\right.$ before sowing $+60 \mathrm{~kg} \mathrm{ha}^{-1}$ at knee height stage +60 $\mathrm{kg} \mathrm{ha}^{-1}$ before tasseling stage) followed by nitrogen application in four splits $\left(45 \mathrm{~kg} \mathrm{ha}^{-1}\right.$ at 
sowing $+45 \mathrm{~kg} \mathrm{ha}^{-1}$ knee height stage $+45 \mathrm{~kg}$ $\mathrm{ha}^{-1}$ before tasseling stage $+45 \mathrm{~kg} \mathrm{ha}^{-1}$ at silking stage) which was statistically at par with application of nitrogen in two splits (90 $\mathrm{kg} \mathrm{ha}^{-1}$ before sowing $+90 \mathrm{~kg} \mathrm{ha}^{-1}$ knee height stage with days to silking). Minimum days to silking were recorded from control. [13] Reported that favorable condition for soil and nutrient availability at a highest dose has nitrogen fertilizer increased the growth of vegetative portion of the plant and delayed the reproductive growth of the maize crop. The results are also in agreement with the $[14,15]$ has concluded nitrogen delayed the phonological phases of plant growth when nitrogen is applied at a highest dose has in three splits which has delayed the silking, tasseling. More days to silking were recorded from Azam variety followed by variety of Jalal. Minimum days to silking were recorded from maize variety Iqbal which was statistically at par Pahari. This variability might be attributed to genetic and/or environmental factor. Similar results were reported by [12].

\section{Days to physiological maturity}

Data regarding days to physiological maturity of maize varieties as influenced by split nitrogen application are shown in (Table 1). Interaction of varieties and split $\mathrm{N}$ application was non-significant. More days to physiological maturity were recorded by application of nitrogen in three split $60 \mathrm{~kg}$ ha ${ }^{1}$ before sowing $+60 \mathrm{~kg} \mathrm{ha}^{-1}$ at knee height stage $+60 \mathrm{~kg} \mathrm{ha}^{-1}$ before tasseling stage followed by nitrogen applied in four splits which was statistically at par with application of nitrogen in two splits. Minimum days to physiological maturity were observed from treatment of control plots. Increase in split $\mathrm{N}$ application splits could maximize photosynthesis rate in plants that might be resulted to increase durability of leaf can delay the phenological characteristics in the maize crop [16, 17]. Ma \& Dwyer [18] stated that nitrogen applied before the silking stage of maize crop may increase the maturity days. [15] also suggested the same results that the reproductive and vegetative stage in maize crop could be delayed by applied nitrogen in splits. Highest days to physiological maturity were recorded from treatment of Azam variety followed by Jalal. Lowest days to silking were recorded from maize variety, Iqbal which was statistically at par with Pahari. This variability might be attributed to genetic and/or environmental factor. Similar results were reported by [12].

\section{Ear diameter $(\mathbf{c m})$}

Table 1 showing the impact of split nitrogen application and varieties of maize had nonsignificance $(P \geq 0.05)$ effect on ear diameter of maize. The combined effect of varieties and split nitrogen application was also nonsignificant. All the means were statistically similar and no significant differences were observed.

\section{Grains row ${ }^{-1}$}

Split nitrogen application and varieties of maize has significantly $(\mathrm{P} \leq 0.05)$ affected the grains row $^{-1}$ indicated in (Table 1). Interaction of split nitrogen application and varieties were also significant. Highest grains row $^{-1}$ were observed by nitrogen application in three splits, i.e. $60 \mathrm{~kg} \mathrm{ha}^{-1}$ before sowing + $60 \mathrm{~kg} \mathrm{ha}^{-1}$ at knee height stage $+60 \mathrm{~kg} \mathrm{ha}^{-1}$ before tasseling stage followed by two split of nitrogen application. Lowest grains row $^{-1}$ were recorded from control plots. Split application of nitrogen delayed leaf senescence, sustained photosynthesis during grain filling period, due to abortion of flowers at the stages of determining the number of ovule per row, decrease of competition and adequate supply of nutrients and, increased the grain row ${ }^{-1}$. Similar results were declared by Aktinoye et al. [19]. Highest value for grains row $^{-1}$ was recorded from maize variety Azam followed by Jalal and Iqbal varieties of maize crop, respectively which is statistically in line with each other. 
Table 1. Days to emergence, emergence $\left(\mathrm{m}^{-2}\right)$, days to tasseling, days to silking, days to physiological maturity, cob height above soil surface $(\mathrm{cm})$, ear diameter $(\mathrm{cm})$ and grain rows $^{-1}$ of maize varieties as influenced by split nitrogen application

\begin{tabular}{|c|c|c|c|c|c|c|c|c|}
\hline $\begin{array}{l}\text { Nitrogen } \\
\left(\mathrm{Kg} \mathrm{ha}^{-1}\right)\end{array}$ & $\begin{array}{c}\text { Days to } \\
\text { emergence }\end{array}$ & $\begin{array}{c}\text { Emergence } \\
\mathbf{m}^{-2}\end{array}$ & $\begin{array}{l}\text { Days to } \\
\text { tasseling }\end{array}$ & $\begin{array}{l}\text { Days to } \\
\text { silking }\end{array}$ & $\begin{array}{c}\text { Days to } \\
\text { physiological } \\
\text { maturity } \\
\end{array}$ & Grains row $^{-1}$ & $\begin{array}{c}\text { Ear } \\
\text { diameter } \\
(\mathbf{c m}) \\
\end{array}$ & $\begin{array}{c}\text { Grain } \\
\text { yield (t ha- } \\
\text { 1) } \\
\end{array}$ \\
\hline $\mathrm{N}_{0}$ & 8 & 7 & $56 \mathrm{c}$ & $61 \mathrm{c}$ & $99 \mathrm{c}$ & $22 \mathrm{~d}$ & 3.5 & $2.5 \mathrm{c}$ \\
\hline $\mathrm{N}_{1}$ & 9 & 8 & $58 \mathrm{bc}$ & $63 \mathrm{bc}$ & $101 \mathrm{bc}$ & $24 \mathrm{c}$ & 3.6 & $2.6 \mathrm{c}$ \\
\hline $\mathrm{N}_{2}$ & 8 & 8 & $59 \mathrm{abc}$ & $64 a b c$ & $102 \mathrm{abc}$ & $27 b$ & 3.7 & $3.4 \mathrm{~b}$ \\
\hline $\mathrm{N}_{3}$ & 8 & 7 & $62 \mathrm{a}$ & $67 \mathrm{a}$ & $105 \mathrm{a}$ & $29 a$ & 3.7 & $4.1 \mathrm{a}$ \\
\hline $\mathrm{N}_{4}$ & 8 & 7 & $60 \mathrm{ab}$ & $65 \mathrm{ab}$ & $103 a b$ & $24 \mathrm{c}$ & 3.7 & $3.4 b$ \\
\hline \multicolumn{9}{|l|}{ Varieties } \\
\hline Pahari & $8 b$ & $7 \mathrm{c}$ & $58 b$ & $63 b$ & $101 b$ & $23 \mathrm{c}$ & 3.6 & $3.1 \mathrm{~b}$ \\
\hline Azam & $8 \mathrm{ab}$ & $8 \mathrm{ab}$ & $61 \mathrm{a}$ & $66 a$ & $104 a$ & $26 a$ & 3.7 & $3.3 \mathrm{a}$ \\
\hline Jalal & $8 \mathrm{ab}$ & $7 \mathrm{bc}$ & $60 \mathrm{ab}$ & $65 \mathrm{ab}$ & $103 \mathrm{ab}$ & $25 b$ & 3.6 & $3.2 \mathrm{ab}$ \\
\hline Iqbal & $9 \mathrm{a}$ & $8 \mathrm{a}$ & $58 b$ & $63 b$ & $101 b$ & $25 b$ & 3.6 & $3.2 \mathrm{ab}$ \\
\hline LSD for Nitrogen & Ns & $\mathrm{ns}$ & 3.79 & 3.85 & 3.8 & 1.2 & $\mathrm{~ns}$ & 0.16 \\
\hline LSD for Varieties & 0.73 & 0.41 & 2.68 & 2.69 & 2.71 & 0.6 & $\mathrm{~ns}$ & 0.15 \\
\hline Interaction & Ns & ns & Ns & Ns & ns & 1.4 & ns & ns \\
\hline
\end{tabular}

\section{$\mathrm{N}_{0}=$ control (Zero nitrogen)}

$\mathrm{N}_{1}=180 \mathrm{~kg} \mathrm{ha}^{-1}$ before sowing

$\mathrm{N}_{2}=90 \mathrm{~kg} \mathrm{ha}^{-1}$ before sowing $+90 \mathrm{~kg} \mathrm{ha}^{-1}$ at knee height stage

$\mathrm{N}_{3}=60 \mathrm{~kg} \mathrm{ha}^{-1}$ before sowing $+60 \mathrm{~kg} \mathrm{ha}^{-1}$ at knee height stage $+60 \mathrm{~kg} \mathrm{ha}^{-1}$ before tasseling stage

$\mathrm{N}_{4}=45 \mathrm{~kg} \mathrm{ha}^{-1}$ before sowing $+45 \mathrm{~kg} \mathrm{ha}^{-1}$ at knee height stage $+45 \mathrm{~kg} \mathrm{ha}^{-1}$ before tasseling stage $+45 \mathrm{~kg} \mathrm{ha}^{-1}$ before silking stage

ns $=$ non-significant

Mean of the same category followed by different letters are significantly different from each other at $5 \%$ level of significance using LSD test 
Lowest value for grains row $^{-1}$ was observed in Pahari variety of maize crop. Similar results have been reported by Roy \& Biswas [20] who reported that the number of grains row $^{-1}$ was significantly affected by maize hybrids.

\section{Grain yield (kg ha-1)}

Grain yield of maize was significantly influenced by split nitrogen application as well as varieties are presented in (Table 1). Interaction of split nitrogen application and varieties had non-significant effect. Maximum grain yield was recorded from nitrogen in three split application i.e. $60 \mathrm{~kg}$ $\mathrm{ha}^{-1}$ before sowing $+60 \mathrm{~kg} \mathrm{ha}^{-1}$ at knee height stage $+60 \mathrm{~kg} \mathrm{ha}^{-1}$ before tasseling stage followed by application of nitrogen in four splits i.e. $45 \mathrm{~kg} \mathrm{ha}^{-1}$ before sowing $+45 \mathrm{~kg} \mathrm{ha}^{-}$ ${ }^{1}$ knee height stage $+45 \mathrm{~kg} \mathrm{ha}^{-1}$ before tasseling stage $+45 \mathrm{~kg} \mathrm{ha}^{-1}$ at silking stage. Lowest grain yield was observed from control. The application of nitrogen in three equal splits has ensured the availability of nitrogen at all the essential growth stages of the maize crop. The losses of nitrogen were reduced due to split application which facilitated efficient uptake of nitrogen during growing season of maize crop. [21, 22] reported that split nitrogen application has ensured high yield performance in maize crop. Among varieties, maximum grain yield was harvested from Azam followed by Jalal and Iqbal. Lowest grain yield $\mathrm{kg} \mathrm{ha}^{-1}$ was recorded from Pahari variety. The higher grain yield recorded for Azam variety could be due to maximum grains row ${ }^{-1}$, ear length (data not shown) and thousand grains weight (data not shown) that ultimately increased grain yield.

\section{Conclusions}

Based on the findings obtained it is concluded from the study that application of nitrogen at the rate of $180 \mathrm{~kg} \mathrm{ha}^{-1}$ in three splits i.e. at $60 \mathrm{~kg} \mathrm{ha}^{-1}$ (before sowing) $+60 \mathrm{~kg}$ $\mathrm{ha}^{-1}$ (at knee height stage) $+60 \mathrm{~kg} \mathrm{ha}^{-1}$ (before tasseling stage) delayed the phonological attributes of different maize varieties and resulted in maximum grain yield. Among varieties, Azam showed maximum grains rows $^{-1}$ which leads to a contributing traits in yield production of maize. Thus, application of nitrogen in three splits $\left(60 \mathrm{~kg} \mathrm{ha}^{-1}\right.$ before sowing $+60 \mathrm{~kg} \mathrm{ha}^{-1}$ at knee height stage +60 $\mathrm{kg} \mathrm{ha}^{-1}$ before tasseling stage) to Azam variety of maize is recommended for higher grain yield under the agro-climatic conditions of Peshawar region.

\section{Authors' contributions}

Conceived and designed the experiments: MM Anjum \& M Shafi, Performed the experiments: MM Anjum \& Jehanzeb, Analyzed the data: N Ali \& MO Iqbal, Contributed materials/ analysis/ tools: S Ullah \& Shafiullah, Wrote the paper: H Ahmad.

\section{References}

1. Chaudhry AR (1983). Effect of $\mathrm{N}$ application and $\mathrm{N}$ spliting strategy on maize Nuptake biomass production and physio-agronomic characteristics. Sarhad J Agric 26(4): 551-558.

2. MNFSR, (2015). Agriculture Statistics of Pakistan. Ministry of National Food Security and Research, Islamabad, Pakistan.

3. Moser SB, Feil B, Jampatong S \& Stamp $P$ (2006). Effects of pre-anthesis drought, nitrogen fertilizer rate, and variety on grain yield, yield components, and harvest index of tropical maize. Agric Water Manage 81: 41-58.

4. Grant CA, Peterson GA \& Campbell CA (2002). Nutrient considerations for diversified cropping systems in the northern great plains. Agron J 94: 186198.

5. Uhart SA \& Andrade FH (1995). Nitrogen deficiency in maize: II. Carbon-nitrogen interaction effects on kernel number and grain yield. Crop Sci 35: 1384-1389.

6. Walsh OS (2006). Effect of Delayed Nitrogen Fertilization on Corn Grain 
Yields. M. Sc. Thesis. Graduate College. Oklahoma State Uni Oklahoma.

7. Rizwan M, Maqsood M, Rafiq M, Saeed M \& Ali Z (2003). Maize (Zea mays) Response to split application of nitrogen. Inter J Agric Bio 1560-8530.

8. Rashid A, Ahmad N, Ahmad S \& Ahmad $T$ (1993). Source sink relationship in maize under varying nitrogen regimes. Pak Agric Res 14(2): 173-176.

9. Rehmati H (2009). Effect of plant density and nitrogen rates on yield and nitrogen use efficiency of grain corn. Applied Sci J 7(8): 958-961.

10. Jan MT, Shah P, Hollington PA, Khan MJ \& Sohail Q (2009). Agriculture research: design and analysis, a monograph. Agric Univ Pesh Pak.

11. Belfield S \& Brown C (2008). Field Crop Manual: Maize. A Guide to Upland Production in Cambodia NSW Department of Primary Industries. 7-8.

12. Khalafalla MM (1993). Evaluation of maize (Zea mays L) genotypes for general and specific combining ability. M.Sc Thesis, Faculty of Agriculture, University.of Khartoum, Sudan.

13. Dolan MS, Clapp CE, Allmaras RR, Baker JM \& Molina JAE. (2006). Soil organic carbon and nitrogen in a minnesota soil as related to tillage, residue and nitrogen management. Soil Tillage Res 89: 221-31.

14. Sharifi RS (2016). Effects of time and rate of nitrogen application on phenology and some agronomical traits of maize (Zea mays L.). Biologija 62(1): $35-45$.

15. Khaliq T, Ahmad A, Hussain A \& Ali MA (2008). Impact of nitrogen rate on growth, yield and radiation use efficiency of maize under varying environments. Pak J Agric Sci 45(3): 17.

16. Gungula DT, Kling JG \& Togun AO (2003). Maize predic-tions of maize phenology under nitrogen- stressed conditions in Nigeria. Agron J 95: 892899.

17. Oikeh SO, Kling JK, Horst W \& Chude VO (1997). Yield and N-Use efficiency of five tropical maize genotypes under different $\mathrm{N}$ levels in the moist savanna of Nigeria. In: Proceedings of the fifth Eastern and Southern Africa regional maize Conference, Addis Ababa: CIMMYT, 163-167.

18. Ma BL \& Dwyer LM (2000). Maize kernel moisture, carbon and nitrogen concentrations from silking to physiological maturity. Canad J Plant Sci 121: 225-232.

19. Aktinoye HA, Lucas EO \& Kling JG (1997). Effect of density of planting and time of nitrogen application on maize varieties in different ecological zone of West Africa. Com Soil Plant Analysis 28: 1163-1175.

20. Roy SK \& Biswas PK (1992). Effect of density and detopping following silking on cob growth, fodder and grain yield of maize (Zea mays L.). J Agric Sci 114: 297-301.

21. Debele T \& Bedadi B (2016). Effect of drain depth of vertisols, nitrogen source and time of application on yield and yield components of maize (Zea mays L.) In ambo, western Ethiopia. Inter $J$ Res Studies Agric Sci 2(6): 1-9.

22. Sarafraz R \& Marashi SK (2015). Effect of split application of nitrogen fertilizer on quantitative and qualitative characteristics of maize under water deficit condition. Indian J Fund Appl Life Sci 5(1): 172-178. 